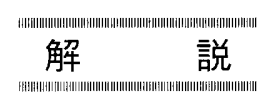

\title{
概念の認知研究の動向：Back to the Feature
}

\author{
河 原 哲 雄 \\ 東京大学大学院教育学研究科*
}

著名な進化生物学者であり, 科学エッセイの名手で もあったS.J.グールドのあるエッセイの中に、こんな 逸話が紹介されている。「海軍山身の老水夫がこんな 話をしてくれた，動くものには敬礼をし，動かないも のにはペンキを塗れ，船上で生活する上でこの単純な ルールさえ忘れなければ，人海原でも道を呮ることは ないとり」もち万んこの水大の棖には，符「の （！）洿㸡が含まれているのだが，事物を複数の概念 (動くもの 動かないもの) によって分類し，それぞ れに心じた行動(敬礼するくペンキを涂る)を選択す る能ノが，生物が環境へと適仙するために不仃火の要 热であることには疑いがない，概念とは, 最も一般的 には，羿知聥程を媒介する内部表現である。したがっ て，あらゆる缌知過程の研究で，概念とその処理が問 題になる.Medin"'は，概念が果たしている機能とし て7つをあげている。（1）分類，（2）理解と説明, (3) 子测, (4) 推渝, (5) コミュニケーション, （6）概念の組み令わせ（概念絬命），（7）小例の牛: 成.このうち（1）の分類が，他のすべての機能の前 提であり，梁知心理受の概念研究のほとんどにおいて， 検泟:と理渝化の刘像とされてきた㙨能である。概念処 理のニューラルネットワークモデルの多くも，事象の

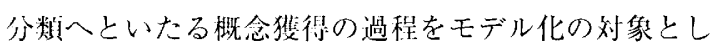

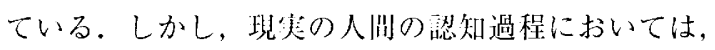
分数を行うことに体が標であることはむしろ稀であ る。これまで损喟されてきた概念のモデルや理諭に， これらの機能のすべてをあらゆる埸闬で説明するよう なものは份作しない。

\section{1. 概念研究の方法}

琹知心理学においては，人䦌の㴓知機能を支える概 念の性筫の解明を目指して，人工カテゴリを用いた概 念学翟実験や, 门然カテゴリの性質の検討, 幼见の概 念発達や科学的概念の発展過程の観察, メタファーや 概念絬合といった新たな概念生成過程の检㳔など， 様々な方法で研究が進められてきた。概念の認知心理

\footnotetext{
* 于113-0033 東京都文京区本郷 7-3-1
}

学について, 入門的な概観は, 河原”にある。また心 理学におけるニューラルネットモデル研究の概観は, 守・都築・楠見" および都築・河原・楠見引を参照さ れたい, 本稿では, 認知心理学に詳しくない䘪者が多 いであ万うことを踏まえ，基本事項についてはこれら の概説との重複を恐れず，しかし近年の係争中の研究 についても紹介寸る.忆も近华，その意味づけが開 い肖されつつある，概念表現の構成素たる特性（feature）の開题に焦点を当てる。

\section{2. 定義的特性モデルからプロトタイプモデルヘ}

1970年代の認知心理学に扮ける概念研究の大きな流 れは, 定義的特性観から特徵的（確率的）特性観への 変化である". 概念研究のみならず, 認知心理学全般 にとっても先駆的業䋶であるBrunerら"の概念学習 研究では, あらかじめ固定されたいくつかの次元で值 が変化する幾何学図形のセットが刺激として用いられ た。たとば,「网形のタイプ」次元の值として, 丸, 三的, 纠角があり,「四形の他」次心の值としてト， 黑，灭色がある刺激セットに执いて，「れから门」, 「黑であるならば二沎」といった，あらかじめ設分さ れた正概念を, 被験者が事例の経験老通じて问定する に至るプロセスを検討した。こうした策験に扔ける概 念を構成している特性は, 単独では必要条件 (その概 念の事例はすべてその特性を持たなければならない) であり，命わせれば㤋条作（それらの特性すべてを 持つ対称は，必ずその概念の事例である）であるとい う意味で, 定義的特性である。 ある料物が, あるカテ ゴリの成只であるかどうかは，そのカテゴリの公義的 特性を持っているか㔻かで疑問の余地なく決まる。こ のような慨念のモデルは，等義的特性モモデルまたは占 典的モデルとよばれる。

定義的特性モデルは，数学的概念や親族概念の上う な名義種（nominal kind）カテゴリにはよく適合する。 だが, 多くの自然カテゴリでは必要十分条件となる䇥 義的特性の集合索決定しがたい (Wittgenstein ${ }^{8)}$ が指 摘した「ゲーム」の概念）柆塞が知られている。また， 
定義的特性モデルでは，自然カテゴリに見られる典型 性効果を説明できない。

Rosch and Mervis ${ }^{9 !}$ は, 自然カテゴリにはカテゴリ 所属を決定する必要十分条件となるような定義的特性 は存在せず，すべてではないが多数の事例に其有され ている特性の重なり合いが事例間に成り立つ家族的類 似性（family resemblance）の構造を持つと主張した。 このような特性は, 定義的特性に刘して特徵的 (characteristic) 特性とよばれ，またカテゴリ分類に 確凉的に寄与するという意味で確率的特性ともよばれ る. Roschらが主張の主要な根拠としたのが，自然力 テゴリに扔ける典型性効果の存在である. 典型性とは, ある事例が，あるカテゴリのどれだけ典型的な成員で あるかの度合いである。たとえばスズメとペンギンは どちらも鳥カテゴリの成員であるが，鳥としての典型 性は，スズメのほうがずっと高い。この典型性の值は, 被験者に直接評定させたり，各次元の川心傾向を算出 したりして得ることができるが，一般に同一文化内で はかなり其通性が高く, 安定した值をとることが知ら れている。この典型性が高い事例ほど, カテゴリ所属 判断文に対する真偽判断が速くて正確であり，また自 由斗生課題において想起頻度が高いといった倾向（典 型性効果）が見られる. Roschら は, 典型性効果は, 自然カテゴリの家族的類似性構造を反映した結果であ るとした，家族的類似の構造を前提とした概念学翏モ デルの一つがプロトタイプモデルである.

プロトタイプモデルでは概念が，多くの所属事例に 共通する特徵からなるプロトタイプを中心に構成され ていると主張する。ある事物があるカテゴリの成員と なる度合いは，その事物の表現とプロトタイプ表現の 間の類似性から算出される.プロトタイプモデルでは, 必要十分条件からなる定義が不可能な概念の存在や, 典型性效果といった定義的特性モデルでは説明が困難 な現象が説明できる. 問題点としては，このモデルで は概念の表象が中心傾向からなると想定しているのに 刘して，人䦌は中心傾向以外の分布情報にも敏感であ ることがあげられる11. しかし，これらの問題点（打 よび範例モデルとの対比で明らかになる弱点）とは別 に, 研究者が恣意的に構成した抽象的な刺激構造を用 いるのではなく，外界に扔ける特性の大域的な構造を 問題にし，被験者による特性リストの産出や典型性の 評定といった手法を開発したことの意義は大きい。

\section{3. 範 例 モ デル}

特徽的特性観にもとづくもう一つの概念学習モデル に，範例（exemplar）モデルがある。範例モデルで
は，プロトタイプのような要約的記述を想定せず，概 念はそれに所属する個々の事例によって表現されてい るとする．ある事物がどのカテゴリに所属するかの決 定に際しては，その項目と比較して，最も類似性が高 い事例が所属していたカテゴリが採用される。此較プ ロセスや類似性の計算方法により，いくつかのバリエ ーションが存在するが, Medin and Schaffer ${ }^{12 !}$ の文脈 モデル (context model) が代表的である。捨象する 情報が少なく，また特性間の相互作用を考慮した類似 性の計算が可能であることから，典型性效果以外にも， 特定事例や特性相関, 文脈の效果といった, プロト夕 イプモデルでは説明の困難な現象も将现することがで きる. Nosofsky ${ }^{13,147}$ の一般化文脈モデルでは, 次元へ の選択的注意の配分が可能であり，カテゴリ学習や記 憶再認，意思決定などに四する膨大な実験虾尖を統一 的に説明できる.

Kruschke $^{15}$ の ALCOVE (Attention Learning Covering Map）は，範例モデルとコネクショニスト モデルのそれぞれの利熙を兼ね備えたモデルである。 ALCOVEでは，事例を構成する特性次元に刘心する人

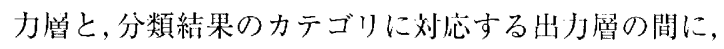
経験した事例の一つつに対応するユニットからなる 隠れ曾が設定される，それぞれの事例ユニットは，入 力刺激との類似性に㐫じて活性化し, それらの重みつ き総和が出力ユニットの活性值となる，そのため，範 例モデルと同等の分類成績が可能になる。また，エラ 一駆動型の学習メカニズムにより, 学㑭過程, 特に各 次元への選択的注意が尖現できる.ALCOVEは, 適切 な次元への注目, 特性间相関の影響, 基準比率の無視 効果, 基潐比㻭の逆転効果, 高頻度の例外が存在する 場合のU字型学翟曲線といった宏験デー夕を再垷する ことが可能であり，またノイズや十渉への頑健性にも 優れている.

\section{4. 理論ベースモデル}

プロトタイプモデルや籁例モデルといった特徽的特 性観にもとづくモデルは，概念表象の形成や新事例入 の一般化が, 経験した多数の事例問で計算された類似 性の值にもとづいて行われるという点が共通してい る. その意味で，これらのモデルをまとめて類似性に もとづく学習 (Similarity-Based Learning, SBL) モデ ルとよぶことができる. 理論ベースの概念理論は，こ うした類似性にもとづく概念モデルが，人間の概念の モデルとしては不十分であるという批判から発したも のである ${ }^{(6)}$. 批判の論点の山で最大のものは, 類似性 にもとづく観点では, 概念の凝集性（coherence）を 
説明できないというものである，概念の凝集性とは， 人間が自然に使用しているカテゴリに見られる，成員 の白然なまとまりのことである．理論ベースの概念理 論では，概念は世界に存在する (多くの場合は素朴な) 理論に支えられており, それらの理論が概念の獲得や 体制化を制約していると考える.理論べースモデルは, 概念の凝集性を説明できると主張する。概念の属性は, 背後にある理論に扔ける知識構造の山で, それぞれが 果たしている役割によって相互に絬び付けられてい る。問題点としては，「理論」にどのような制約が棵 せられるべきかが分明らかにされておらず，具体的 な表現形式やアルゴリズムの提案にそしいこと，また 認知過程一般に扔いて類似性が果たしている役割を軽 視しすぎであることなどがあげられる.

理論ベースの概念理論门体は, 概念学習の計算過程 を迟式化していないが，機械学瓷の分野における説仃 にもとづく学殞 (Explanation-Based Learning, EBL) モデルは，その就の吣的な部分を金现している と考えられる，EBLでは，概念学䙹に执いて知淺が果 たす役制を車視し，知識が豊富な領域では，雷一事例 からでも新概念の獲得が叮能であるとする。

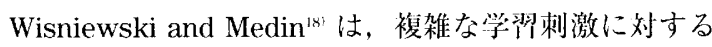
ルール帰約課題を用いて, 概念学垍に扔けるSBL的な プロセスとEBL的なプロセスの閒の関係を検㨽した。 先騟の一つでは，子供の描いた人物面のセットを素材 として，「創造性の高い子供が描いた絵，非㓱造的な 子供が描いた絵」というラベルを付扠することによっ て, 被験兴が州納する分類ルールがどのように変化す

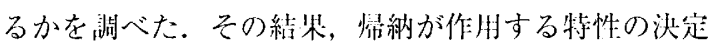
やその解釈が，トップダウン的な理論的期待と, ボト ムアップ的な経䮖的証拠の滥の複杂倠な相巧作用を通じ て行われることが明らかになった。

\section{5．類似性と構造整列}

従来の類似性にもとづく概念モデルでは，類似性の 郆算方法にバリエーションはあったものの，姑算の刘 解を特性のフラットなリストで表現し，それぞの特性

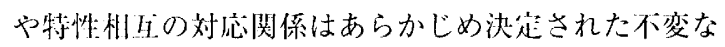
ものと考える点は其通であった，説明にもとづく学習 では，特性䦚に説明の連鎖という一つの夕イプの構造 を導入したわけであるが，一力で特性の関係構造・般 を考虑に入れることで，類似性を再考しょうとする動 きも現れてきた。そその代表的な観点が, 類似性の構造 整列（structural alignment）理論である。この観点で は、類似性比較をアナロジ推論における特像のような, 複雑な構造対応の過程を含むものと考える。このプロ

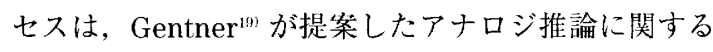
構造写像理論に由来するものである。構造写像理論は, Falkenhainer ${ }^{203} の$ Structural Mapping Engine (SME) として，計算モデルの形で実装されている．SMEは 記号処理的なモデルであるが，局所表現を用いた制約 充足ネットワークによって, 複雑なシーン間の類似性

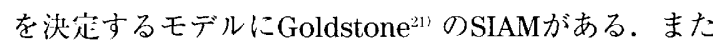
分散衣垷を用い，関係を表す述語への項の動的束縛を エニットの同期的発火で行うことで，より乘軟な刘忍 づけを可能にしたアナロジ写像のモデルに, Hummel and Holyoak ${ }^{22}$ のLISAがある.

構造整列では，比較のプロセスを通じて，刘敆の間 に構造的に一貫した刘忍つけを行う。整列の結果，関 係の其通性によって対応関係におかれた要素の閁の庤 買は，整列可能（alignable）な差晎とよばれる。それ

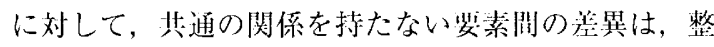
列代叮能（nonalignable）な养簧とよばれる。比較に 扔いては，其通性のみならず整列可能な差異が重望な 役制を演じる，階層性と類似性を統制した熘毘ぺアを 用いて，被験者に共通点と相違点をリストアップさせ る課題を行わせた研究注では, 共通性と整列叮能な差 異の間には正の相関が見られたが, 整列不叮能な养翼 との開には負の相関が見られた。 Markman and Gentner $^{24}$ の実験では，被娩者に図式的な状沉を描い た絵のペアを提示して，一方のシーンにある刘象と刘 応する対象を，他方のシーンから選ばせる課題を行わ せた，絵のペアには，見かけが類似しているが異なる 関係的役割を果たしている対象と，見かけが異なるが 類似した関係的役割を果たしている対像が，それぞれ 含まれていた (父差写像の関係)。最初から絵のペア を提示された群の被験者は，類似して見える対象を硔 択する傾向があった。これに対して，まず2つの状況 の類似性を 9 段階詊価し，その後に対応するものを選 択させられた群の被験者は，類似した役割を果たして いる対象を選ぶ傾向が強かった。この結果は, 類似性 比較を行うことで関係的な対応への注意が促されるこ と，(特性の刘志を白明で不変なものとみなす類似性: にもとづく概念モデルの想定とは異なり）刘岕づけが 事例の比較プロセス中に行われるダイナミックな過程 であることを示唆している.

Schyns and Rodet ${ }^{225 !}$ は, 「火星人の細胞」という設 定の，アメーバ状の染みを組み合わせた网形のカテゴ リ学習実験において, 刺激を提示する順序を変化させ ることで，物理的には同・の部分が，単--の特性と解 积されたり，複数の特性の連言と解釉されたりするこ とを示した。 すなわち, 特性の存在や解彩白体が, 概 
念学習の過程で文脈によって変化してしまう場合があ る.こうした特性の解釈自体の変化は，子供の絵のよ うな現実的な対象を用いたWisniewski and Medin ${ }^{(8)}$ の 研究でも観察されている。これらの研究は，概念表現 を特性リストとみなしてきた多くの概念学習の計算モ デルの前提に反して，刺激を表現する過程白体が，複 雑な諗知プロセスであることを示したものである.

\section{6. 概念の階層性}

概念には，より抽象性の高い上位の概念に包含され たり，より具体性の高い下位カテゴりを包含したりと いった階風関係がある。こうした階層構造は，効率的 に推論を行うために車要である。一般に，上位概念で は, 刘比概念との弁別性は帛いが, 概念に含まれる事 例问上の類似性は低くなる倾向がある。逆に，下位概 念では, 概念以に含まれる事例同士の類似性は高いが, 刘比概念との手别性は低くなる傾问がある. Rosch ${ }^{12 !}$ は, 自然概念の階層構造において, 最も情報量が多く て日常的に有用な，中程度の抽碾レベルである，基礎 レベル（basic level）が存在すると主張した。たとえ ば「家具－椅子－座卓」という階層では「椅了」，「哺 乳類一犬ーシェパード」という階層では「犬」が基礎 レベル概念に相当する，基礎レベル概念はまた，発達 の過程で早期に獲得され，事物を同定したり呼称した りする茎面で吱も自然に使われる概念であるとされ る. 一方, 発達や熟達化の進行につれて, 基儊レベル に相当する水準が変化する場合があることが知られて いる.

基礎レベル概念の三振は，人間の使用するカテゴリ が, 叮能なカテゴリ構造の山で，なんらかの基準一カ テゴリの情報洒（informativeness）一を最適化したも のであろうという発想にもとづいている. しかし，力 テゴリ妥当性（カテゴリ所窝を所ケとした時の属性值 の生起確率) や子がかり妥当性（属性做を所与とした 時のカテゴリ所属の確摔）といった基準は，基礎レ心゙ ルの上うな中䦌的な水準のカテゴリの優位性を予測す ることができない，前者の基集を最大化するとただ 1 つの事例からなるカテゴリ，後者の基準を最大化する とすべての事例を含むカテゴリが得られてしまうから である. Corter and Gluck ${ }^{2(2)}$ は，情報理論的分析によ って，両者の基準を統合したカテゴリ効用（category utility）基準を作り出した。一方，Markman and Wisniewski ${ }^{277}$ は，同じ上位カテゴリに属する基礎レべ ルカテゴリ間の非類似性の多くは整列可能な差異であ るのに対して，異なる上位カテゴリ間にはほとんど共 通性がない（整列不可能な差異）ことを指摘して，基
礎レベル概念の優位性はカテゴリの分類学的構造に由 来すると主漲している。

\section{7. 概念のタイプ}

認知心理学で研究されてきた概念には，様々な夕イ プのものが含まれる．まず，研究方法に関して重要な のは，自然概念と人工（artificial）概念の区別である. 门然概念とは，自然言語内の名辞や，有機体の亣別必 応と対応し，人間の口常的で自然な知覚・認知過程に 由来すると考えられる概念である。これに対して人て 概念とは，人間またはプログラムによってメンバー所 属のルールがあらかじめ明示的に決定されている概念 である，人工概念は，自然概念が持つと考えられる性 質の一部を取り出して定式化したり，異なるカテゴリ 学習のモデル間で人間のパフォーマンス（学摺の相刘 的な難易度や転移反心のパタン等）を予測する能力を 比較したりするのに用いられる。

自然概念の中では， 然種と人亡物概念の区别が再 要である。自然種（natural kind）とは，回然界に存 在し，科学的探究の対像となりうる事物に関する概念 であり，生物や鉣物などが含まれる，生物概念に関し ては，内部構造や子孫に関する属性が本質であるとい う信念が共有されており，それが概念としての凝集性 の源であるとされる。それに刘して人工物（artifact） 概念は，道具や機械といった，人間が仙らかの月標を 遂行するために作り出した事物に関する概念である。 人亡物概念においては，製作者の意図についての信念 が本質的役割を果たすという信念が其有されており， それが概念としての凝集性の源であるとされる。

自然概念の多くは，意味記憶に販藏されるある程度 安定的な概念であると考えられるが，人洴はその場の 月標や文脈に伈じて，一時的に新奇な概念を構成する ことができる。こうして生成される概念を，ゴール依 存型概念またはアドホック概念という。たとえば「火 事のときに持ち出すもの」というカテゴリには，企庫， 位牌，赤ん坊といった，通常はひとまとめにされない ような事物が含まれる。これらの事物は，あるゴール が少えられたとたんにひとまとめにされる。アドホッ ク概念は，自然カテゴリと问様な少型性効果等の性質 を示す2"が，それぞれの概念に所属する事例には，特 性レベルでの共通性はほとんど見られない，

\section{8. 特 性 の由 来}

類似性にもとづく概念モデルでは, 特性はどれも平 等に扱われるので，経験した事例にたまたま含まれて いた無意味な特性が, 概念の記述に含ま机てしまう場 
命がある。一方, 説明ベースの学習では, 説明に用い られなかった特性は無視されるが，そうした特性も概 念の䛉述に不必要とは言い切れない場合がある(例： 「禹球」概念に扔ける「白い」)。そこで，概念のコア と同定手続きを区別することが提唱されだ。概念の コアとは, 成員の所属を科学的に定我したり, 熟考の 上で決定する際に用いられるような，本質的な特性か らなる分類ルールである。たとえば，「文性」概念に 扔ける「XX染出体を持っている」という特性がこれ にあたる。これに刘して，「笼が辿い」「スカートをは いている」といった，とりあえずの㴓職に川いられる が，取終们には間連いを導く叮能性があるような特性 からなる分類ルールが间分丁続きである。さらにここ うした概念䛉述における本質们部分と衣而的部分の関 倸についての人々の腤黙の理解の什うを表悓したの

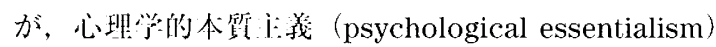

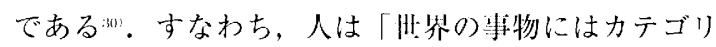

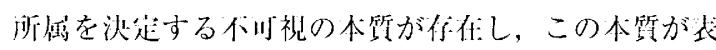

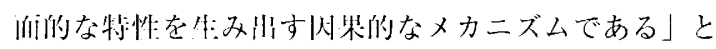

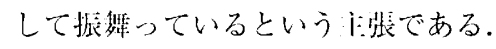

\section{9. 特性分布の大域的構造}

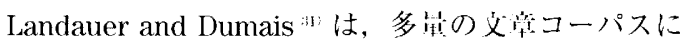
扔ける简望の其起関保に刘して，刚子分析の一般化で ある特買做分解を適川する淄任意味分析 (latent semantic analysis：以トではLSA）を開発した. LSA

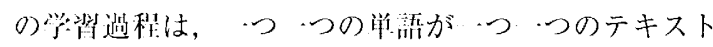
文脈に川垷する㺫数をからントすることから始まる。 たとえば，门科拓典を川いた例では，約30,0000段落 に約35,000の罢なる衙が会まれていた。こうして段 落×涪の]门人な行列が得られる。LSAは，この行列に 特異值分解を適川儿て, 空間の次元を人幅に繀減古る。 すなわち，特買值の人半を捈てて，人きいほうから

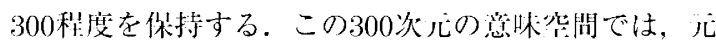
の行列に扔ける搵や文其をべタトルとして表现するこ とができる。また，新たな峾や文监をこの突閒に挿人

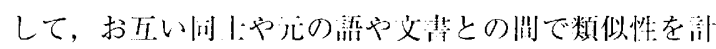

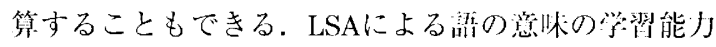
は非常に強了であり，尖归的な水潐に達するものであ った。百科事典の例では，分析から得られたべタトル を为いて，槽準涪策テストの解答を選抓したところ， LSAの成績は，中程度に優秀な学釉（介橎同の大学に 合格した外国人応募省のTOEFL）の成績に㠩敵する

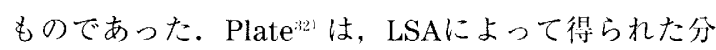
散表現を, 言棓処理のコネクショニストモデルに適用 する可能性を示唆している，LSAがホした優れた学
習・般化能力は，知識表現の基底となる特性として， 客観的で再利用可能な集合を選択できる可能性を示峻 している点できわめて重姴である.

McRaeら ${ }^{3: 331}$ は，特性産出課題を用いて被験者の概念 に関する知識を取り出し，そこから大規模な単語セッ トの特性表現を構筑する研究を行った。鳥, 哺乳類, 果物, 野菜, 衣類, 家具, 台所用品, 道具, 乗り物, 武器の計10のカテゴリにつき各19の其体物の概念を対 奚とし，得られたデータから1242のユニットを持つ特 性ユニットからなる単独特性ベクトルと，11900ユニ ットからなる相闺特性べクトルを構築した。これらの 特性表現から汁算した類似性の值を，自動的意味プラ イミングのような宫速な認知処理の卣験デー夕に適用 したところ，单独特性による颣似性は，人.丁.物概念に おけるプライミング效果をケ測したが，生物概念にお ける效果を子測しなかった。逝に相開特性による類似 性は，牛物概念のプライミング刘柴を予測したが，人 门.物概念の効果を予測しなかった。庆，類似性語分 のような低速の衿知処理の主験デー夕に適刀した絬果 は，単独特性䉼似性は人「物においても生物において

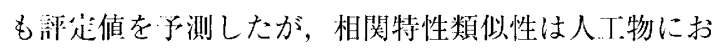
いても生物に扔いても評定値を予測しなかった。ホッ プフィールド学㥜則を用いて特性相関をコード化した アトラクタネットワークを同いたシミュレーションを 行った結果は，これらの垁験デー夕をよく再现した。 许独特性で表现された情報は部の意味の計算の初期段 階で, 相関特性で表現された情報は後期の仪束段階で, それぞれ中心的役制を果たすこと，またこれら情報の 用いられ方が生物カテゴリと人に物カテゴリで異なる ことが明らかになった。

これらの研究は，大規模な尖デー夕から適切な仕うj で縮約された特性:表现が，人問の概念的知裸の大局的 構造の 面を捉えうることを示している。

\section{0. 神経心理学的知見とモデル}

概念の構造に関する神䋂心理学似な知㒻として，脎 批㑺が意味記憶に対してカテゴリ特買な障赛をもたら す場合があることが知られている。たとえば，非生物 と比較して動物や植物の分類が闲難になる症例州や, 逆に生物の分類には䦌题がないのに道具のような非生 物の分類が相難になる症例沙観察されている。これ らの事実は一見すると，生物や非牛物といった概念が 異なる下位モジュールに賏蔵されていることを示唆し ているように思われる。だがWarrington and McCarthy ${ }^{3 i 1}$ はこうした解離が，生物は主に知覚的特 性にもとついて分類が行われるのに対して，人工物で 
は機能的特性（作成者の意罒など）にもとづいて分類 が行われるといったモダリティの違いに由来する可能 性を示唆している. Farah and McClelland ${ }^{377}$ は,こう したモダリティの違い（知覚的／機能的）を組み込ん だコネタショニストモデルを構築し，知営領野や機能 領野に相当する部分のリンクや結合荷重の・部を消去 することで，生物／非生物に特異的な障害を再現でき ることを示した．さらにDevlinら ${ }^{388}$ およびTylerら は, 機能的特性の弁別力や，機能的特性と知覚的特性 の相関といったカテゴリ構造上の変数が意味領域によ り異なることを考慮に人れ，特定領域に限定されない 拡散性の損傷でもカテゴリ特異な障害が生じる事実を 再現するコネクショニストモデルを構留した．カテゴ リ特異な障害については, 現在も論争が継続してい る圳が，概念の領域による特性の分布や相関の構造の 違いを考慮に入れなければ十全な理解とモデル化が叶 わないという点では, 多くの研究者が一致している.

\section{1.まとめと展望}

概念の垫知科学研究を，その構成素である特性の問 題に焦点を絞りながら駆け足で概観した（関速する論 点を含む概念発達や概念結合については, 割愛せざる を得なかった)。概念の獲得・使用プロセスの実験研 究では, 従来の静的でフラットな特性観に疑閭が呈さ れ, 特性の表现過程そのものが動的・構造的で創造的 なプロセスであることが明らかになってきた。..」で, 大规模な言語コーパスを用いた研究では，特性次元を 適切な自由度に在縮することで, 人間の概念能力のか なりの部分を捉える可能性があることが示された。ま た，神経心理学的な症例扔よびシミュレーション研究 からは, 概念の領域による特性構造の違いが重要であ ることが示唆された。これらの動们を，つつの理論な いしモデルのゆで統合的に説明することは，今のとこ ろ不问能である。しかしそれは概念という問題領域の 大きさによるものであって，マクロ（長期の学岶・発 達を通じて獲得される構造）とミクロ(オンラインで の学㱛・使用過程）の屾面で, 特性観が人きく変わり つつあることは閒違いない, 現状でいえるのは, 前者 については, 類似性や特性分布が人開の概念の凝集性 を提えられないとしてきた理論べースの概念観などの 主朗に反して，人間を取り巻く概念環境には，適切な 表現方法とアルゴリズムを用意することで抽出可能に なるような特性構造が存在すること，人㯕が䒠際にそ のような特性構造を脳内に表現している可能性がある こと. 後者については，人䦌の概念学装プロセスが従 来考えられてきたよりもずっと構造指向的なものであ
ることである.これらは合わせて，概念の表現と学習 が，今後とも研究に值する問題であることを物話って 余りある.

従来, 神経回路網モデルを含む多くの概念表現・学 習モデルに打いて，個々の特性ユニットは作成者が丁 動でコード化したり，ランダムに牛成して表現したも のであった。そうした研究は，モデルの訃算諭的な限 界を測るなどの用途では今後も伯用性を失わないであ ろう。しかし，人閒の概念能力の本質を捉えようと試 みるのであれば，本稿で紹介した特性というものの多 様なありカや，それがもたらす幾多の問題を避けて通 ることは，もはやできないと考えられる。

\section{参 考 文 献}

1) Gould,S.J. (1983): Hen's Teeth and Horse's Toes, New York: W.W.Norton（邦訳：「ニワトリ の宷（上）」，第3章，「グアノ・リング」，渡边政 隆, 三中信宏訳, 東京：早川書房（1998））

2 ) Medin,D.L. and Goldstone,R.L. (1990) : Concept, In M.W.Eysenck(Ed.), The Blackwell Dictionary of Cognitive Psychology. Cambridge, MA : Basil Blackwell Inc.（邦訳：「認知心理学碚典」，野島 久雄, 重野 純, 半田智久訳, 束京: 新曜社 (1998))

3 ) 河原哲雄 (2001)：概念の構造と処理, 人上知能 学会誌, Vol.16, No.3, pp.435-440

4) 守一雄, 都築䇾史, 楠見隆編 (2001)：コネク ショニストモデルと心理学, 京都：北大路萻房

5 ) 都築答史, 河原哲雄, 楠見 孝 (2002) : 高次浔 知過程に関するコネクショニストモデルの動咁, 心理学研究, Vol.72, pp.541-555

6 ) Smith,E.E. and Medin,D.L. (1981):Categories and Concepts, Cambridge, MA :Harvard University Press

7 ) Bruner, J., Goodnow,J. and Austin,G. (1956) : A Study of Thinking. New York: Wiley（那訳: 「思考 の研究」, 岸本 弘, 岸本紀子, 杉本垫義, 山北 亮訳，果京：明治汹青 (1969))

8 ) Wittgenstein, L. (1953) : Philosophical Investigations. New York : Macmillan (邦訳：「哲学探究」, 藤本隆志訳, 束京：大修館昔店 (1993))

9 ) Rosch,E. and Mervis,C.G. (1976) : Family resemblances: Studies in the internal structure of categories, Cognitive Psychology, Vol.7, pp.382- 439

10) Rosch,E., Mervis, C. G., Gray, W. D., Johnson, D. M. and Boys-Braem,P. (1976): Basic objects in natural categories, Cognitive Psychology, Vol.8, pp. $382-439$

11) Ashby,F.G. and Gott,R.E. (1988) : Decision rules in the perception and categorization of multidimensional stimuli, Journal of Experimental Psychology: Learning, Memory, and Cognition, Vol.14, 
pp. $33-53$

12) Medin,D.L. and Schaffer,M.M. (1978) : Context theory of classification learning, Psychological Review, Vol.85, pp.207-238

13) Nosofsky,R.M. (1988) : Exemplar-based approach to relations between classification, recognition, and typicality, Journal of Experimental Psychology: Learning, Memory, and Cognition, Vol.14, pp.700-708

14) Nosofsky,R.M. (1992): Exemplar-based approach to relating categorization, identification, and recognition, In F.G.Ashby (Ed.), Multidimensional Models of Perception and Cognition. (pp.363 - 393) Hillsdale,NJ:Erlbaum

15) Kruschke,J.K.(1992): ALCOVE: An exemplarbased connectionist model of category learning, Psychological Review, Vol.99, pp.22-44

16) Murphy,G.L. and Medin,D.L. (1985): The role of theories in conceptual coherence, Psychological Review, Vol.92, pp.289-316

17) Mooney,R.J.(1993) : Integrating theory and data in category learning, In G.V.Nakamura, R.Taraban and D.L.Medin (Eds.), The Psychology of Learning and Motivation: Categorization by Humans and Machines, Vol.29.(pp.189-219) Sandiego,CA: Academic Press

18) Wisniewski,E.J. and Medin,D.L. (1994) : On the interaction of theory and data in concept learning, Cognitive Science, Vol.18, pp.221-281

19) Gentner,D. (1983) : Structure-mapping : A theoretical framework for analogy, Cognitive Science, Vol.7, pp.155- 170

20) Falkenhainer,B.,Forbus, K.D. and Gentner,D. (1989) : The structure mapping engine: Algorithm and examples, Artificial Intelligence, Vol.41, pp.1-63

21) Goldstone (1994) : Similarity, interactive activation, and mapping, Journal of Experimental Psychology: Learning, Memory, and Cognition, Vol.20, pp.3-28

22) Hummel,J.E. and Holyoak,K.J. (1997) : Distributed representation of structure: A theory of analogical access and mapping, Psychological Review, Vol.104, pp. $422-466$

23) Markman,A.B. and Gentner,D. (1993) : Splitting the differences: A structural alignment view of similarity, Journal of Memory and Language, Vol.32, pp.517-535

24) Markman,A.B. and Gentner,D. (1993) : Structural alignment during similarity comparisons, Cognitive Psychology, Vol.25, pp.431 - 467

25) Schyns,P.G. and Rodet,L. (1997) : Categorization creates functional features, Journal of Experimental Psychology: Learning, Memory, and Cognition, Vol.23, pp.681-696
26) Corter,J.E. and Gluck,M.A. (1992) : Explaining basic categories: Feature predictability and information, Psychological Bulletin, Vol.2, pp.291 - 303

27) Markman,A.B. and Wisniewski,E.J. (1997) : Similar and different: The differentiation of basic level categories, Journal of Experimental Psychology: Learning, Memory, and Cognition, Vol.23, pp.5470

28) Barsalou,L.W. (1983) : Ad hoc categories, Memory and Cognition, Vol.11, pp.211-217

29) Armstrong,S.L., Gleitman,L.R., and Gleitman,H. (1983) : What some concepts might not be, Cognition, Vol.13, pp.263-308

30) Medin,D.L. and Ortony,A. (1989) : Psychological essentialism, In S.Vosniadou and A.Ortony (Eds.), Similarity and Analogical Reasoning. Cambridge,England: Cambridge University Press

31) Landauer,T.K and Dumais,S.T. (1997) : Solution to Plato's problem: The latent semantic analysis theory of acquisition, induction, and representation of knowledge, Psychological Review, Vol.104, pp. $211-240$

32) Plate, T. (1999): Representation, reasoning and learning with distributed representations, In A.Jagota, T.Plate, L.Shastri and R.Sun (Eds.), Connectionist Symbol Processing: Dead or Alive? Neural Computing Surveys, Vol.2, pp.1-40

33) McRae,K.,de Sa,V.R. and Seidenberg,M.S. (1997) : On the nature and scope of featural representations of word meaning, Journal of Experimental Psychology: General, Vol.126, pp.99-130

34) Warrington, E. K. and Shallice, T. (1984) : Category specific semantic impairment, Brain, Vol.107, pp. $1237-1296$

35) Warrington,E. K. and McCarthy,R. (1983) : Category specific access dysphasia, Brain, Vol.106, pp. $859-878$

36) Warrington,E.K. and McCarthy,R. (1987) : Categories of knowledge: Further fractionation and an attempted integration, Brain, Vol.110, pp.12371296

37) Farah,M.J. and McClelland, J. L. (1991) : A computational model of semantic memory impairment: Modality specificity and emergent category specificity, Journal of Experimental Psychology: General, Vol.120, pp.339-358

38) Devlin,J., Gonnerman, L., Andersen, E and Seidenberg, M. (1998) : Category specific deficits in focal and widespread brain damage: A computational account, Journal of Cognitive Neuroscience, Vol.10, pp.77-94

39) Tyler, L. K., Ross, H. M., Durrant-Peatfield, M. R. and Levy, J. P. (2000) : Conceptual structure and the structure of concepts: Distributed account of category-specific deficits, Brain and Languge, 
Vol.75, pp.195-203

40) Humphreys, G. W. and Forde,E.M.E. (2001) : Hierarchies, similarity, and interactivity in object recognition: "Category-specific" neuropsychological deficits, Behavioral and Brain Sciences, Vol.24, pp.453-509 